\section{Chris Saunders}

Emeritus Professor, Department of Historical

Studies and Research Associate, Centre for

Social Science Research, University of Cape Town. chris.saunders@uct.ac.za

DOI: https://dx.doi.org/ 10.18820/24150509/

JCH42.v1.6

ISSN 0258-2422 (Print) ISSN 2415-0509 (Online)

Journal for

Contemporary History

2017 42(1):99-114

(c) UV/UFS

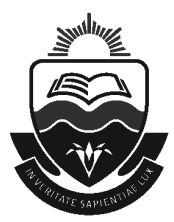

\section{DECOLONIZATION IN SOUTHERN AFRICA: REFLECTIONS ON THE NAMIBIAN AND SOUTH AFRICAN CASES}

\begin{abstract}
While the term "decolonization" is now applied in many different situations, with different meanings, its original and prime usage relates to the process leading to the ending of colonial rule. Though there is a large literature on that process, we lack a detailed overview of the way it unfolded in Southern Africa. This article focuses on two countries in that region, Namibia and South Africa, and raises some of the questions that need to be addressed in relation to their "decolonization". It also seeks to show how complex "decolonization" was in these two instances, and the importance of seeing individual cases in a regional and comparative perspective.
\end{abstract}

Keywords: Colonialism; decolonization; comparative studies; South Africa; Namibia.

Sleutelwoorde: Kolonialisme; dekolonisasie; vergelykende studies; Suid-Afrika; Namibië.

\section{INTRODUCTION}

The term "decolonization" is today used in many different ways. A seminal text dealing with decolonization in a broad sense, still frequently referred to, but first published as long ago as 1986, is Decolonizing the mind. It was written by the Kenyan novelist and post-colonial theorist, Ngũgĩ wa Thiong'o, who picked up on ideas articulated over a decade earlier by Steve Biko in South Africa. ${ }^{1}$ In recent years "decolonization" has become a new buzzword on many South African university campuses, usually with no clear meaning except that it is linked to "transformation". Though the term was first used in the early twentieth century in a general sense by one who had experienced colonialism in Southern Africa at first hand, ${ }^{2}$ when the term gained general currency after the Second World

$1 \quad$ Steve Biko, I write what I like (London: Bowerdean Press, 1978).

2 Robert Gordon, "Moritz Bonn, Southern Africa and the critique of colonialism", African Historical Review 45(2), 2013, pp. 1-30; 
War, it referred to the process leading to the end of colonial rule, as in India in 1947 and then, from 1957, in countries in Africa. This was a process that often culminated in a ceremony marking the advent of independence from the colonial power. ${ }^{3}$ But because the structures and effects of colonialism may endure after formal independence, post-colonial thinkers, such as Franz Fanon and Edward Said, saw decolonization as an ongoing process, while some rejected the term because it seemed not to accord prime agency to those who struggled for what they called "national liberation". ${ }^{4}$ Here the term will be used primarily in the political sense of the ending of formal colonial rule.

While there is now a large literature on decolonization in general in the late twentieth century, as well as studies of the ways it took place in particular cases, for instance in West Africa or tropical Africa as a whole, ${ }^{5}$ there is, surprisingly, no major study in English of the process in the Southern African region that addresses the main questions that need to be asked. This article seeks to raise some of these questions in the cases of Namibia and South Africa, with the aim of beginning to show how complex "decolonization" was in these two instances, and how necessary it is to see the process in a regional and comparative context.

As we shall notice, it is not easy to determine when decolonization in Southern Africa began. If, however, it ended with the advent of formal independence, a set of dates present themselves, for example, Mozambique and Angola became independent from Portugal in 1975, Zimbabwe from Britain in 1980, Namibia from South Africa in 1990. Another viewpoint is to see decolonization taking place in Southern Africa in three distinct phases. In the first of these, the small countries of Botswana, Lesotho and Swaziland became independent in the 1960s through constitutional processes and without armed struggles. In a second phase, following the Carnation Revolution in Portugal

Cf. John Springhall, Decolonization since 1945. The collapse of overseas European empires (London: Palgrave, 2001), p. 3.

3 See, for example, Robert Holland, Susan Williams and Terry Barringer (eds), The iconography of independence: "Freedoms at midnight" (London: Routledge, 2010).

4 See, for example, Springhall, p. 3.

5 The literature in English includes John D Hargreaves, The end of colonial rule in West Africa: Essays in contemporary history (London: Macmillan, 1979); John D Hargreaves, Decolonization in Africa (London: Longman, 1988; $2^{\text {nd }}$ ed. 1996); David Birmingham, The decolonization of Africa (Athens, Ohio: Ohio University Press, 1995); Norrie Macqueen, The decolonization of Portuguese Africa. Metropolitan revolution and the dissolution of empire (London: Longman, 1997). More recent books on other parts of Africa include Elizabeth Schmidt, Cold War and decolonization in Guinea, 1946-1958 (Athens, Ohio: Ohio University Press, 2007). For decolonization in general, see, especially, John Darwin's seminal article on "Diplomacy and decolonization", The Journal of Imperial and Commonwealth History 28(3), 2000; Anthony Hopkins, "Rethinking decolonization", Past \& Present 200(1), 2008, pp. 211-247. Cf. also Christopher C Saunders, "The transitions from apartheid to democracy in Namibia and South Africa in the context of decolonization", Journal of Colonialism and Colonial History 1(1), Fall 2000. 
in April 1974, independence came to Mozambique and Angola after protracted armed struggles and without elections, while in a third phase, Zimbabwe gained its independence in April 1980 and Namibia in March 1990.

While, for a time in the late 1970s, policy-makers in London and Washington expected Rhodesia and Namibia to move to independence in tandem, ${ }^{6}$ this did not happen, and when independence came to those countries, a decade apart, it was in very different contexts, though in both cases independence not only followed lengthy conflicts, but also negotiated settlements and democratic elections. Only when each case is placed in its own particular context, can we assess how the one relates to the other. A recent book on Rhodesia/Zimbabwe from 1965 to 1980 has a sub-title that promises that that particular example of a decolonization process would be seen in context of the broader African decolonization, but fails to deliver on that promise, presumably because the author lacked the knowledge to make good on it. She does not, for instance, begin to explore how similar or different decolonization in the Namibian case was from that of Rhodesia/Zimbabwe. ${ }^{7}$

To explore some of the complexities involved in decolonization - such as what it involved, when it can be said to begin, and what it meant - I firstly consider the case of Namibia, then that of South Africa, before offering some general reflections.

\section{NAMIBIA}

Namibia is the only example of decolonization in Africa south of the equator in which the colonial power was the next-door neighbour. ${ }^{8}$ That Namibia lay across the Orange River from South Africa meant that it was relatively easy for white South Africans to settle there, and some settlers from the colonial regime that preceded South Africa, that of Germany, had remained after German rule gave way to South African occupation. Thus, in Namibia, as in Mozambique and Angola, territories long considered by the colonial power, Portugal, to be "overseas provinces", parts of the metropole, there was a sizeable settler population. In all three countries lengthy wars were fought against the colonial powers, ${ }^{9}$ but in neither Angola nor Mozambique was there an effective

6 See, for example, Nancy Mitchell, Jimmy Carter in Africa. Race and the Cold War (Stanford: Stanford University Press, 2016).

7 Luise White, Unpopular sovereignty. Rhodesian independence and African decolonization (Chicago: University of Chicago Press, 2015). On the Zimbabwean case see, especially, Mordechai Tamarkin, The making of Zimbabwe. Decolonization in regional and international politics (London: Frank Cass, 1990).

8 Eritrea, in the Horn of Africa, regained its independence from Ethiopia in 1991.

9 On the Portuguese colonies, see Macqueen; Miguel Bandeira Jerónimo and António Costa Pinto (eds), "International dimensions of Portuguese late colonialism and decolonization", Portuguese Studies 2(2), 2013. On Algeria see, especially, Matthew 
negotiated transition to independence. Most of the settlers left as independence approached and no elections were held before a liberation movement took power. In Namibia, by contrast, there was a long process of negotiation, involving constitutional provisions for the post-independence era, and an election was held for a constituent assembly in November 1989. What especially sets the Namibian case apart from those of Mozambique and Angola, is that the former colonial power, South Africa, retained enormous power over its former colony at independence. In Namibia not even sovereignty over the new nation's only significant port, Walvis Bay, was transferred when the territory became independent in 1990. It was not until 1994 that Walvis Bay was reintegrated into independent Namibia. ${ }^{10}$

While South Africa ruled Namibia from the time it conquered the territory from Germany in 1915, it was not able to annex it. It wished to do so at the end of the First World War, but the victorious powers insisted that all the former German colonies fall under the new League of Nations. In 1920 the mandate over the territory, under the League, was given to South Africa, which meant South Africa could rule it as if it was an integral part of its territory, but with consideration for the interests of the indigenous population. When the United Nations (UN) was formed after the Second World War, South Africa again sought to annex Namibia, but, conscious of the segregationist policies South Africa was employing, the UN forbade this. Though the League was no longer in existence, the mandate therefore continued, but, as South Africa began to apply apartheid laws in Namibia, the International Court of Justice (ICJ) in The Hague was asked to determine whether South Africa's rule of Namibia was not contrary to the spirit of the mandate and whether South Africa's rule should not therefore be said to be illegal. ${ }^{11}$ After the case was dismissed on a technicality in mid-1966, the UN General Assembly voted to terminate the mandate. Namibia then fell, in theory, under the authority of the UN. Once the ICJ had, in 1971 in an Advisory Opinion, said that South Africa's rule of Namibia was illegal and that South Africa should withdraw, the UN Security Council began to consider how to put pressure on South Africa to withdraw from the territory. Many countries called for mandatory economic sanctions against South Africa, but the leading Western countries, with strong trade links to South Africa, resisted such calls, and instead, in 1977, formed a so-called Western Contact Group (WCG) to negotiate a transition from South African rule to independence. ${ }^{12}$ The following year the WCG persuaded

Connelly, A diplomatic revolution: Algeria's fight for independence and the origins of the post-Cold War era (Oxford and New York: Oxford University Press, 2002).

10 See Chris Saunders, "South Africa and Namibia: Aspects of a relationship", South African Journal of International Affairs 23(3), November 2016, pp. 347-364.

11 The most recent study is Ryan M Irwin, Gordian knot: Apartheid and the unmaking of the liberal world order (New York: Oxford University Press, 2012).

12 For a summary, see, for example, Chris Saunders, "The Western contact group". In: G Martel (ed.), Encyclopaedia of diplomacy (New York: Wiley-Blackwell, 2017 
both South Africa and the South West Africa People's Organization (SWAPO) to accept a plan that provided for a UN presence in Namibia during a transition period.During that period an election for a constituent assembly was to be held, but in terms of the WCG plan South Africa was allowed to continue to administer the territory until independence. Though this plan was embodied in UN Security Council Resolution 435 of 1978, for a decade South Africa resisted implementing it. Only in 1988, after suffering a severe set-back in the war it fought in southern Angola to prevent SWAPO from operating from there, did the South African government engage in negotiations with Cuba and Angola, under United States mediation. An agreement was hammered out providing for the implementation of Resolution 435, alongside the withdrawal of Cuban forces from Angola. The UN then sent a Transition Assistance Mission to Namibia and from April 1989 the UN played a key role in the formal transition to independence. South Africa, however, remained the de facto colonial ruler of the territory until, on 21 March 1990, the UN Secretary General presided over a ceremony at which the South African flag was lowered and the new flag of an independent Namibia was raised. ${ }^{13}$

Namibia has sometimes been referred to as Africa's last colony, suggesting that 1990 closes the story of African decolonization. ${ }^{14}$ How valid is the idea that Namibia's independence marked the end of a long decolonization process; one that had started in Asia after the Second World War and, for tropical Africa, with the grant of independence by Britain to the Gold Coast in 1957? France and Belgium soon followed Britain's lead in granting independence to their African colonies. Portugal is sometimes referred to as having had "the last empire" in Africa, because it resisted decolonization longer than the other European colonial powers. There is the anomalous case of Rhodesia, where Britain returned to rule directly for a few months before handing over power to the new Zimbabwe government in April 1980, five years after Mozambique and Angola became independent. Some recent scholarship has drawn new attention to the idea of a South African "empire" in Southern Africa, ${ }^{15}$ which might suggest that South Africa should perhaps be seen as the last "imperial" power on the continent. By allowing Namibia to become independent, it could be argued, South Africa's formal "empire" came to an end.

forthcoming).

13 Lionel Cliffe et al., The transition to independence in Namibia (Boulder: Lynne Reiner, 1994); Lauren Dobell, SWAPO's struggle for Namibia (Basel: Basel Afrika Bibliographien, 1998); Chris Saunders, "The role of the United Nations in the independence of Namibia", History Compass Journal 5(3), May 2007, pp. 737-744.

14 See, for example, R Green, M Kiljunen and K Kiljunen (eds), Namibia: The last colony (Harlow: Longman, 1981).

15 See, for example, the special issue of the Journal of Southern African Studies 41(3), 2015 on the South African Empire. 


\section{SOUTH AFRICA}

Does the transfer of power in South Africa in May 1994, when Nelson Mandela's government took office, mark the end of African decolonization? South Africa's Truth and Reconciliation Commission saw the events of 1960 to 1994 [sic] in Southern Africa as, "the last great chapter in the struggle for African decolonization". ${ }^{16}$ Yet South Africa had a special status. Its formal position as a colony of Great Britain ended in 1931 with the passage by the British Parliament of the Statute of Westminster, which gave South Africa, as a dominion, full independence within the British Empire.

A South African liberal critic of racial segregation advanced the idea in 1944 that white minority rule was in itself a form of colonial rule, and this idea was elaborated in the 1950s and 1960s by both liberals and the South African Communist Party (SACP). ${ }^{17}$ The latter saw South Africa both as a sub-imperial power in the region, doing the bidding of imperial powers elsewhere ${ }^{18}$ and as an example of what it termed "colonialism of a special type". This was, the SACP said, "a variant of capitalist rule in which the essential features of colonial domination in the imperialist epoch are maintained and even intensified", but where, "the colonial ruling class with its white support base on the one hand, and the oppressed colonial majority on the other, are located within a single country". ${ }^{19}$ The idea of "colonialism of a special type" was taken up, for example, by the World Conference against Colonialism, Racism and Apartheid in Southern

16 Final Report of the Truth and Reconciliation Commission, Volume I (Pretoria: South African Government, 1998), 25 (par. 5). President Mbeki spoke of a new decolonized South Africa playing a leading role in an African Renaissance, a rebirth of the entire continent.

17 Leo Marquard first put forward the idea in a book he published under the name John Burger (pseud.), The black man's burden (London: Gollancz, 1944). He elaborated on the idea of, what he called, internal colonialism in South Africa's colonial policy; the presidential address he delivered at the annual meeting of the Council of the South African Institute of Race Relations (Johannesburg: Institute of Race Relations, 1957). The Communist Party's theory of "colonialism of a special type" is analyzed in C Bundy, "Around which corner? Revolutionary theory and contemporary South Africa", Transformation 8, 1989.

18 According to the South African Communist Party, "[in] the colonial system of imperialism in southern Africa, the economies of the countries of the region were structured to be highly dependent on South Africa in terms of communication and transport, the supply of manufactured goods and, to an extent, even the employment of wage labour. South Africa emerged as a sub-imperialist centre, a junior partner of imperialism seeking to dominate the region on its own behalf and on behalf of imperialism". "The path to power", Programme of the South African Communist Party", <http://www.sacp. org.za/main.php?ID=2638>.

Ibid. 
Africa, held in June 1977 in Lisbon in the aftermath of the independence of Mozambique and Angola. ${ }^{20}$

In the 1980s the view that South Africa was still to be decolonized is found implicitly in two major published collections on African decolonization, co-edited by Prosser Gifford and William Roger Louis, both of which included a chapter on South Africa. ${ }^{21}$ Subsequent writings similarly accepted that in South Africa a particular form of settler colonialism existed, despite the absence of a distinct metropole, and that the country had to undergo a process of internal decolonization, with power transferred from the white minority to the black majority. ${ }^{22}$

Since such a transfer of power took place in 1994, another body of writing has appeared that sees that process as similar to what had taken place elsewhere in Africa, with one elite group taking over from another, ushering in a period of neo-colonialism. In both Namibia and South Africa, it is said, "bargains" or "pacts" were made by which the incoming nationalist parties agreed to concessions, as had their predecessors in earlier cases of African decolonization. ${ }^{23}$ In both Namibia and South Africa these essential compromises were embodied in a set of constitutional principles, to which the main parties agreed. In the Namibian case the WCG, under the leadership of the United States, persuaded both the South African government and SWAPO to accept such principles in $1982 .{ }^{24}$ In South Africa the FW de Klerk government insisted on constitutional continuity and, in December 1993, South Africa's new democratic constitution, incorporating a set of constitutional principles, including a Bill of Rights, was approved by the Multi-Party Negotiating Forum at Kempton Park outside Johannesburg in November 1993, and then ratified by the outgoing apartheid-era Parliament. ${ }^{25}$

20 See, for example, the statement from The World Conference for Action Against Apartheid, Lagos, Nigeria, August 1977, which referred back to the Lisbon Conference, <http://www. anc. . .. za/show. .php?id=4233>.

21 L. Thompson, "The parting of the ways in South Africa". In: P Gifford and WR Louis (eds), The transfer of power in Africa (New Haven: Yale University Press, 1982); S. Nolutshungu, "South Africa and the transfers of power in Africa". In: P Gifford and WR Louis (eds), Decolonization and African independence: The transfers of power 19601980 (New Haven: Yale University Press, 1988).

22 See, for example, F Welsh, History of South Africa (London, Kodansha, 1998), p. xxvii.

23 See, especially, Patrick Bond, Elite transition (Rev. ed., London: Pluto Press, 2014).

24 See, especially, Marinus Wiechers, "Namibia: The 1982 constitutional principles and their legal significance", South African Yearbook of International Law 15, 1989/1990; Dawid van Wyk, "The making of the Namibian Constitution: Lessons for Africa", The Comparative and International Law Journal of Southern Africa 24(3), November 1991; Nico Horn, "The forerunners of the Namibian Constitution", <http://www.kas.de/upload/ auslandshomepages/namibia/constitution_2010/horn.pdf>.

25 See, for example, FW de Klerk, The last trek - A new beginning: The autobiography (New York: St. Martin's Press, 1999), pp. 291-292; Adrian Guelke, South Africa in transition: 
Such an evolutionary transition, based on compromises, has represented for some the "selling out" of the revolutionary cause for which the liberation struggles were fought. The transfers of political power in Namibia and South Africa, it is argued by John Saul and others, masked a lack of transformation in other areas of life, most significantly in the social and economic condition of the majority of the population. ${ }^{26}$ The successor governments of Nelson Mandela, Thabo Mbeki, Kgalema Motlanthe and Jacob Zuma are seen as having been so constrained by the continuing legacies of apartheid rule and the power of global capitalism that they have been unable to change the fundamentals of the liberal capitalist economic system or pursue a radical agenda that would bring true freedom to the masses. From this perspective, political emancipation was little more than a sham; true liberation is still not in sight. ${ }^{27}$

The idea that South Africa underwent a form of decolonization in 1994 helps to alert us to the ways in which decolonization takes different forms at different times. South Africa had, after all, experienced an earlier form of decolonization as it moved from direct rule from the British metropolis to independence within the Empire, and, ultimately, to withdrawal from the Commonwealth in 1961 after the decision was taken to become a republic. Some Afrikaner republicans did not regard "their" country as being truly independent until that happened. Despite all the international hostility directed at white-ruled South Africa, both because of apartheid and because the international community recognized that South Africa's rule of Namibia was illegal, South Africa continued to be recognized in international law as a sovereign independent country - even if it was one that was, in the eyes of the UN General Assembly, guilty of what the Assembly in 1973 called "a crime against humanity". ${ }^{28}$ Though South Africa was forced to withdraw from the General Assembly the following year, it remained a member of the UN and continued to participate in Security Council debates. However, it increasingly became a pariah in the international community due to its apartheid policies, applied in both Namibia and South Africa, and its refusal to withdraw from Namibia.

The misunderstood miracle (London: IB Tauris \& Co Ltd, 1999) and cf. E Osaghae, "The global and regional contexts of South Africa's democratic transition", Politikon 23(2), 1996; E Osaghae, "The missing (African) link in the comparative analysis of South Africa's transition", African Sociological Review 1(2), 1997.

26 See, for example, John Saul, Recolonization and resistance: Southern Africa in the 1990s (Trenton: Africa World Press, 1993), p. 4; John Saul, A flawed freedom: Rethinking Southern African liberation (Claremont: University of Cape Town Press, 2014).

27 An early example of this argument is MJ Murray, The revolution deferred: The painful birth of post-apartheid South Africa (London: Verso, 1994). Later variants include D McKinley, The ANC and the liberation struggle: A critical political biography (London: Pluto Press, 1998).

28 "The International Convention on the Suppression and Punishment of the Crime of Apartheid" was adopted by the UN General Assembly with Resolution 3068(XXVIII) of 30 November 1973. 
After the Second World War, as the international community began to give greater attention than before to human rights - most notably in the Declaration of Human Rights adopted by the UN in 1948 - South Africa moved in the other direction, towards greater diminution of human rights and repression. The claim by the South African Prime Minister, Hendrik Verwoerd, that his "grand apartheid", or Bantustan policy, would deliver greater rights and freedoms to the country's black population gained no traction in the international community, and, as we will notice, no other country recognized the Bantustans that were given nominal "independence". ${ }^{29}$

A series of steps took colonies from dependent status in the British Empire to independent membership of the Commonwealth. The usual view is that South Africa acquired its independent status within the Empire from the time of the passage by the Parliament of the United Kingdom of the Statute of Westminster in 1931, which was in turn adopted into South African law by the Status of the Union Act of 1934. That Act declared South Africa to be "a sovereign independent state" and removed any power of the British Parliament to legislate for South Africa and of the British monarch to grant assent to South African legislation. ${ }^{30}$ Some scholars would, however, argue that power was effectively transferred from the imperial government to the colonies in South Africa much earlier, by grants of responsible government to the Cape Colony in 1872, to Natal in 1893, and then to the former Boer Republics after the South African War at the beginning of the twentieth century. It can even be argued that decolonization began with the British withdrawal from the Transvaal in 1881, if not with the withdrawal from what became the Orange River Sovereignty in 1848, or even the earlier British withdrawal from Queen Adelaide Province in what is now the Eastern Cape in 1836; though in the latter case there was merely a withdrawal without any attempt to hand over power to the indigenous people. ${ }^{31}$ Where there was a hand-over of power, it was to a group of colonists, who were a minority; not to a majority population, as in the case of British devolutions of power in Canada, Australia and New Zealand.

South Africa devolved a measure of power to an internal party in Namibia in 1985, but not "independence", because that would not have been recognized by the international community as legitimate, given the exclusion of the main nationalist movement. If decolonization requires majority rule, South Africa was only decolonized in 1994 when power was at last transferred from a minority to

29 Cf., for example, Saul Dubow, South Africa's struggle for human rights (Auckland Park: Jacana, 2012).

30 See, for example, N Mansergh, The Commonwealth experience: From British to multiracial Commonwealth (Toronto: University of Toronto Press, 1969); John Darwin, Britain and decolonization: The retreat from empire in the post-war world (Basingstoke: Macmillan Educational, 1988).

31 Deryck Schreuder, Gladstone and Kruger (London: Routledge and Kegan Paul, 1969), Foreword. 
the majority through a process generally recognized as legitimate, because it was the result of a democratic process accepted by all parties.

\section{NAMIBIA AND SOUTH AFRICA}

In the eighteenth century the Marquis de Turgot wrote that, "Colonies are like fruits which cling to the tree only till they ripen" ${ }^{32}$ Some scholars have argued that the global consensus changed so drastically after the Second World War that there was no alternative to the process of colonies being led to independence. In reality, however, there was in fact no clear or direct teleology and no agreement on what decolonization meant or what form it would take. Portugal resisted the idea of decolonization long after it was recognized by the UN as essential, and the white settler regimes in Southern Africa long saw it as not only a threat to their own continued hold on power, but as something destructive and even immoral. The example of the decolonization of the Belgian Congo in 1960 was often cited, where it had led to chaos and violence, requiring the intervention of UN forces. After 1960, however, while there was continued resistance to the idea of decolonization - and the reason why the Namibian and South African decolonizations did not occur until long after those elsewhere in Africa was fundamentally the resistance of the white rulers of those countries - there was also an acceptance of the idea that the way to resist decolonization led by nationalist forces prepared to take up arms to achieve their objectives, was to accept another form of decolonization. Addressing the South African Parliament in January 1960, the British Prime Minister Harold Macmillan warned the Afrikaner Nationalist rulers of South Africa that African nationalism was sweeping the continent and bringing about a "wind of change" they would not be able to resist, ${ }^{33}$ and as decolonization gathered pace elsewhere in Africa in that decade, the white rulers come to accept that some kind of decolonization was indeed inevitable. This was aided by examples of relatively peaceful decolonization, which did not lead to instability and chaos, as in the cases of Botswana, Lesotho and Swaziland in Southern Africa. It was realized that the acceptance by the international community of the principle of decolonization as a universal good could not be ignored. South Africa's white minority governments therefore tried to fashion a type of decolonization they could live with.

In the 1960s, South African governments continued to hope that Namibia might become a fifth province of South Africa, at a time when they hoped also to incorporate the British High Commission territories of Bechuanaland,

32 Quoted, for example, in AF Madden and David Fieldhouse, Settler self-government, 1840-1900: The development of representative and responsible government (Westport: Greenwood Publishing, 1985).

33 Cf. Larry Butler and Sarah Stockwell (eds), The wind of change: Harold Macmillan and British decolonization (Basingstoke: Palgrave Macmillan, 2013). 
Basutoland, and Swaziland. To deflect international criticism of apartheid, and to divide internal resistance, South Africa embarked on its Bantustan policy, a form of internal decolonization, which it began to apply in Namibia, as well as in South Africa. The Transkei was led to nominal "independence" by the South African government in October 1976. ${ }^{34}$

By the mid-1970s, in the face of an escalating armed struggle in Namibia and with the ICJ having ruled that South Africa's occupation of Namibia was illegal and that South Africa should withdraw from the territory, the South African government accepted that Namibia should be led toward independence. The South African government therefore abandoned its Bantustan policy in Namibia, which had taken some of the so-called homelands there to self-government, and from 1975 sought to create conditions that would facilitate a hand-over of power to a regime that would rule the whole of Namibia in South African interests. This was the so-called Turnhalle option, and for a time South Africa hoped that the Democratic Turnhalle Alliance (DTA), a grouping that emerged from the meeting in the Turnhalle building in Windhoek, Namibia's capital, would become the ruler of an independent Namibia. The problem was, of course, that no-one would recognize such a government if it came to power thanks to South Africa and through a process that excluded SWAPO, the leading nationalist party, which received recognition by the UN General Assembly in 1976 as the "sole and authentic" representative of the Namibian people.

South African strategy, formulated by Hendrik Verwoerd even before Macmillan's Wind of Change Speech, was to lead the various Bantustans to "independence", but when the Transkei was granted nominal independence no-one but the South African government recognized it, because it was so obviously an apartheid creation. This helped bring home to the South African government that such recognition was essential if a new Namibian government was to have legitimacy and if the conflict with SWAPO was to end. The South Africans slowly came to the view that a new government could include SWAPO if the nationalist party were to agree to return from exile and engage in the political process, and if it could be prevented from being able to write the constitution for an independent Namibia on its own. From the mid-1970s South Africa embarked on a series of attempts to decolonize the territory on South Africa's terms. None of these succeeded, for SWAPO would have nothing to do with any arrangement engineered by the apartheid regime. International recognition required an election in which SWAPO participated and was judged free and fair by an external monitoring authority, which in this case would be the UN. For a long time, South Africa balked at permitting an election to be held under UN auspices,

34 Roger Southall, South Africa's Transkei: The political economy of an "independent" Bantustan (London: Monthly Review Press, 1982); Laura Evans, "South Africa's Bantustans and the dynamics of 'decolonization': Reflections on writing histories of the homelands", South African Historical Journal 64(1), 2012, pp. 117-137. 
in part because it was reluctant to allow the UN, which was regarded as being vehemently opposed to South Africa and an ardent supporter of SWAPO, into the territory, and because SWAPO, the likely winner of such an election, was viewed as a Marxist party. In the 1980s, therefore, South Africa continued to support attempts to form an anti-SWAPO front in Namibia. The DTA became part of a broader Multi-Party Conference in the early 1980s, and then in 1985 South Africa devolved a measure of power to a multi-racial, but unelected Transitional Government of National Unity. Only with the winding down of the Cold War and after fears of a SWAPO victory faded, did South Africa finally agree, in 1988, to allow an election organized by the UN to be held, after which it would withdraw from the territory.

In South Africa in the 1980s, PW Botha's government tried a series of neocolonial strategies, seeking to co-opt black allies. Though the so-called Tricameral Constitution, introduced in 1984, white minority rule was diluted by bringing Coloureds and Indians into the central Parliament, but the all-white National Assembly retained effective power. Schemes for co-opting black African collaborators by giving minor powers to local councilors proved ineffective, as well as counter-productive, for they intensified resistance by the opponents of apartheid. By the time FW de Klerk took over from PW Botha as President in August 1989 it was clear that there was no alternative but to cut a deal with the main South African nationalist movement, the African National Congress (ANC), which had overwhelming international legitimacy as the party claiming majority support. The transfer of power to the ANC after the 1994 election ended attempts at what John Saul and others have called "false decolonization", and the Bantustans were re-incorporated into the nine new South African provinces. ${ }^{35}$

If "true" decolonization requires a transfer of power that enjoys legitimacy in the eyes of the international community, what we cannot know is whether such "true" decolonization of either Namibia or South Africa could have occurred had the Cold War not begun to wind down in the late 1980s. The Cold War long helped the South African government resist moving to accommodation with the nationalist movements both in Namibia and in South Africa itself, and it was only when it began to abate that the South African government agreed to withdraw from Namibia and then to negotiate with the liberation movements in South Africa. ${ }^{36}$ Communism seemed no longer a threat, nor did continued support

35 See, for example, Saul, Recolonization and resistance; Saul, A flawed freedom. Cf. Hein Marais, South Africa limits to change: The political economy of transition (New York: St. Martin's Press, 1998).

36 Cf. Guelke, ch. 2. On the impact of the Cold War on Africa, see F Marte, Political cycles in international relations: The Cold War and Africa, 1945-1990 (Amsterdam: Paul \& Co. Publishing Consortium, 1994); J Spence, "Southern Africa and the Cold War", History Today, February 1999; Chris Saunders and Sue Onslow, "The Cold War in Southern Africa 1976-1990". In: M Leffler and OA Westad (eds), The Cambridge History of the Cold War, Volume III (Cambridge: CUP, 2009); Sue Onslow (ed.) Cold War in Southern 
by the Soviet Union for the liberation movements. It was not coincidental that FW de Klerk made his breakthrough speech, opening the door to a negotiated settlement in South Africa, only three months after the fall of the Berlin Wall in November 1989. ${ }^{37}$

One of the key questions about any case of decolonization is the extent to which it came about as a result of external or endogenous forces. Nationalist writing is obviously inclined to emphasize the importance of local factors in bringing about independence. Recent scholarship, however, has stressed the importance of international factors in, say, the process leading to Algerian independence,,$^{38}$ while the intervention of Cuban forces was crucial to the ability of the Popular Movement for the Liberation of Angola (MPLA) to take power in Luanda in November 1975. ${ }^{39}$ External forces were even more important in the long story of Namibia's decolonization. While independent Namibia celebrates the heroic role that the armed wing of SWAPO, the People's Liberation Army of Namibia (PLAN), played in the achievement of independence, ${ }^{40}$ and while it is true that the armed struggle that PLAN fought from 1966 was essential to the gaining of independence, it is also true that PLAN was not able to win a military victory over the South African Defence Force, and it was external forces that brought the country to independence. The UN played a key role, as did, for example, the international movement in support of Namibian independence. ${ }^{41}$

On the other hand, too great an emphasis on the significance of external factors in bringing about the independence of Namibia may downplay the significance of SWAPO's multifaceted liberation struggle, even if it is accepted that SWAPO was more successful in winning support in the global arena than

Africa: White power, black liberation (London: Routledge, 2009); Hilary Sapire and Chris Saunders, "Liberation struggles in Southern Africa in context". In: H Sapire and C Saunders (eds), Southern African liberation struggles: New local, regional and global perspectives (Cape Town: UCT Press, 2012).

37 Cf. C Saunders, "The ending of the Cold War and Southern Africa". In: Artemy Kalinovsky and Sergey Radchenko (eds), The end of the Cold War and the Third World (London: Routledge, 2010), pp. 264-277.

38 Connelly, passim.

39 By far the fullest and most detailed work on the Cubans in Angola, based in part on Cuban archives in Havana to which he had unique access, is Piero Gleijeses, Visions of freedom. Havana, Washington, Pretoria and the struggle for Southern Africa (Chapel Hill: University of North Carolina Press, 2013).

40 Cf. Christopher Saunders, "Namibia's freedom struggle: The Nujoma version", South African Historical Journal, 2002; Christopher Saunders, "Il racconto del Presidente della Namibia su come la Namibia ha raggiunto l'indipendenza", Afriche e Orienti 2003; Christian A Williams, National liberation in postcolonial Southern Africa. A historical ethnography of SWAPO's exile camps (New York: Cambridge University Press 2015).

41 See, for example, Christopher Saunders, "Namibian solidarity: British support for Namibian independence", Journal of Southern African Studies 35(2), June 2009; Christopher Saunders, "Activism in Britain for Namibia's independence: The Namibia Support Committee”. In: Sapire and Saunders, passim. 
in its armed struggle in the south-west African bush. Though "decolonization" may appear a neutral term, it suggests that colonialism came to an end as a result of outside initiatives. In the decolonization of Namibia UN Security Council Resolution 435 was the key, requiring South Africa's withdrawal from Namibia. South Africa only agreed to implement Resolution 435 under pressure. The winding down of the Cold War increased pressure, as did what happened in South Africa's war in southern Angola. There South Africa had initially intervened to knock out SWAPO's camps and prevent guerrilla incursions into northern Namibia, but over time the South African Defence Force (SADF) found itself in action against the Angolan army and eventually Cuban forces as well. In the early months of 1988 the SADF suffered a severe set-back, if not the military defeat so often cited, at Cuito Cuanavale. Not only could the SADF not gain the upper hand on the ground, but it lost air-superiority. ${ }^{42}$ Though SWAPO played a very minor role in this major clash, it led the struggle against South African occupation of Namibia, and though Umkhonto we Sizwe's (MK) armed struggle never presented a serious threat to the apartheid regime, in the sense of being able to bring about its overthrow militarily - something its first commander-inchief, Nelson Mandela, always realized - its role as "armed propaganda" was hugely significant in challenging that regime. Decolonization came about as a result of liberation struggles, and due weight needs to be given to the dogged determination of the nationalist parties to pursue their struggle against the colonizers, both militarily and by means of diplomacy and propaganda. ${ }^{43}$

Whereas the regional and international context played a greater role in Namibia than in other African cases of decolonization, ${ }^{44}$ in South Africa, by contrast, it was internal resistance in the 1980s that was crucial in moving the country to a transfer of power. What is striking about the South African case is how the parties reached a negotiated settlement by themselves, without significant external pressure..$^{45}$ As apartheid was a particular form of colonial rule,$^{46}$ so liberation from apartheid took a special form. Because the antithesis to

42 Cf. Gleijeses; Gary Baines, South Africa's Border War (London: Bloomsbury, 2013).

43 Cf. Cheikh Anta Babou, "Decolonization or national liberation: Debating the end of British colonial rule in Africa", The Annals of the American Academy of Political and Social Science 632(91), November 2010, pp. 41-54.

44 On the regional aspects, see, especially, Ronald Dreyer, Namibia and Southern Africa (London: Kegan Paul International, 1994).

45 Cf. Chris Saunders, "The dog that didn't bark: The absence of significant international mediation in the South African transition to democracy", Mediation Arguments (University of Pretoria) 5, April 2014. On the South African background, a recent major study is Jamie Miller, An African volk. The apartheid regime and its search for survival (New York: Oxford University Press, 2016).

46 In Citizen and Subject (Princeton: Princeton University Press, 1996), Mahmood Mamdani saw apartheid as a form of colonial rule similar to that found elsewhere in Africa, but subsequently gave more weight to apartheid's distinctive features, e.g. inhis review of I Evans, "Bureaucracy and race", Journal of African History 39(1), 1999, p. 159. 
apartheid was non-racialism and an inclusive democracy, those ideas triumphed in the constitutions of the two countries; the one a new country born of a transfer of power from the colonial rule, the other a country in which power passed from a minority to the majority.

\section{CONCLUDING REFLECTIONS}

For the transitions from apartheid to democracy in Namibia and South Africa, then, we need to ask the same questions as with decolonization elsewhere. Among these are: How important were the pressures exerted by liberation movements? How significant were international actors and the international climate? How did national governments react to the decolonization process as it unfolded in the region? How did decolonization and the Cold War interlink? What effects did the transfers of power have, and to what extent did they lead to fundamental change? We know, say, that the independence of Mozambique and then of Angola in 1975 stimulated resistance to apartheid and fed into the background to the Soweto uprising of $1976,{ }^{47}$ but to what extent did the independence of Zimbabwe, and the coming to power there of Robert Mugabe's Zimbabwe African National Union, encourage the South African regime to dig in its heels and so delay a possible transfer of power? And to what extent was the decolonization process in South Africa "decolonization of a special type" ${ }^{48}$ There are often no easy answers to such questions and sometimes no definitive answer.

Take the question of when decolonization began. While the coup in Lisbon in April 1974 led directly to the independence of Mozambique and Angola the following year, few would suggest that the decolonization processes for those countries began in 1974. Did they begin with the establishment of FRELIMO and the MPLA, or with the beginnings of the two armed struggles? There is scope for different interpretations of the significance of particular events and of what caused significant processes to begin. Let us consider the cases of Namibia and South Africa. Though the independence of Namibia came about as a direct result of a process begun with the implementation of Resolution 435 from 1 April 1989, there was a lengthy process of decolonization prior to that. SWAPO's armed struggle began in 1966; UN Security Council Resolution 435 was passed in September 1978. As we have seen, other forms of decolonization were put in place by the South African government; they did not result in independence. Similarly, in South Africa the apartheid government sought to decolonize on its own terms, giving nominal independence to Bantustans, but it was a parallel

47 See, for example, Jamie Miller, "Things fall apart: South Africa and the collapse of the Portuguese Empire, 1973-74", Cold War History 12, 2012, pp. 183-204.

48 Cf. Christopher Lee, "Decolonization of a special type: Rethinking Cold War history in Southern Africa", Kronos 37, November 2011, pp. 6-11. 
process that led towards the transfer of power in 1994. Some would argue that that process only really began with the break-through speech by President FW de Klerk on 2 February 1990, unbanning the ANC and other organizations. Others might trace the process back to the Soweto uprising of June 1976 or before. The Sharpeville massacre of January 1960 led to the banning of the ANC and its decision, in 1961, to adopt the armed struggle. The ANC had been formed as the South African Native National Congress, as early as 1912, but for long had been a relatively insignificant organization. It is possible to trace the origins of any case of decolonization to many different points in time.

While there may be no definitive answers, only when such questions are explored will we be able to begin to offer substantial comparisons between the various decolonization processes, to trace the interconnections between them, and to explore the patterns that emerge. Only then can we fully understand, for example, to what extent Namibian independence made possible South Africa's "decolonization" four years later. ${ }^{49}$ This article has merely tried to illustrate some of the complexities involved, and to begin to situate the two cases considered here in a broad framework of decolonization. It is hoped that such reflections will provoke thought about how such an analysis may precede with regard to other cases of decolonization in Southern Africa and elsewhere.

49 For attempts to begin to answer this, see, for example, Christopher Saunders, "The transition in Namibia and the South African case". In: N Etherington (ed.), Peace, politics, and violence in the new South Africa (Oxford: Oxford University Press, 1992); Christopher Saunders, "Of treks, transitions and transitology", South African Historical Journal 40, May 1999; Christopher Saunders, "Reflections on the transition from apartheid to democracy", South African Historical Journal 51, December 2004. 